\title{
KRŠĆANSKO TEOLOŠKO-FILOZOFSKO PROPITIVANJE TEMELJA GOSTOLJUBIVOSTI
}

\author{
Ivica Karlo Lapić
}

Centar sv. Ambrozija za psihijatrijsku rehabilitaciju Cernusco sul Naviglio, Italija fragiancarlo@fatebenefratelli.it
UDK: 27-43:338.483.13

https://doi.org/10.34075/cs.55.3.2

Pregledni znanstveni rad Rad zaprimljen 3/2020.

\section{Sažetak}

Provedeno istraživanje u ovoj nam prezentaciji nudi moralnu perspektivu gostoljubivosti u kojoj se sloboda vjerovanja konfigurira kao intencionalnost vjere. Propitivanja u biblijskom i filozofskom dijelu imala su namjeru izdvojiti temeljne strukture gostoljubivosti kao univerzalno antropološke $u$ svojoj teologalnoj vezi i intrinzičnoj ljudskoj dinamici. Kristovo otajstvo, uz premise cjelokupne hermeneutike ljudske gostoljubivosti ocrtane u sujetlu objave, postaje privilegirano teološko mjesto njezinog cjelovitog $i$ konačnog poimanja i njezinog potpunog ostvarenja (Mt 25,31-46).

Fenomenologija intersubjektivnosti predstavlja subjekt $u$ relaciji kao ontološki temelj gostoljubivosti koja u svjetlu objave postaje hermeneutički put i sam razlog njezine vjerodostojnosti. Dinamika međuljudskih odnosa u gostoljubivom odnosu podrazumijeva biti-s-drugim $i$ biti-za-drugoga, u kontinuiranom kretanju otvorenosti prema drugosti u agapičnom poretku. Ta ga dinamika u potpunosti upisuje u temelj registra kršćanskoga moralnog djelovanja.

Izvorni čovjek u biblijskoj objavi pokazuje svoju sposobnost otkrivanja izvorne Božje nakane u gostoljubivoj dobrodošlici, kao čin sujesne i odgovorne slobode za dobrobit drugoga i kao dar i brigu, koji su kadri nadvladati bilo kakvu drugost/razliku, čak i onu najradikalniju.

Ključne riječi: Gostoljubivost, skrb za druge, samopredanost, intersubjektivnost, krepost gostoljubivosti

\section{UvoD}

Promišljanje o konceptu/kategoriji gostoljubivosti kao krjeposti upućuje nas na propitivanje različitih aspekata ljudske egzistencije: od društvenih fenomena povezanih s masovnom migracijom do 
skrbi o ljudskoj ranjivosti općenito. U današnjem društveno-kulturnom kontekstu govor o prihvaćanju drugosti i o gostoljubivosti odmah se dovodi u vezu s fenomenom globalizacije, migracija, interkulturalnosti, drugim riječima, s fenomenom drugosti, s pitanjem prihvaćanja drugog (čitaj različitog) i izazova koje ono predstavlja u aktualnoj socijalnoj strukturi društva. Ovaj aspekt, koliko s jedne strane nameće raspravu o gostoljubivosti, toliko s druge strane ne iscrpljuje njezinu antropološku stvarnost te $u$ isto vrijeme upućuje na urgentnost promišljanja tog koncepta u Crkvi i društvu. Gostoljubivost se nameće našem promišljanju kao fenomen blizak ljudskoj ranjivosti i fenomenu nepovjerenja naspram svega onog što je drugo i drugačije, strano i različito u odnosu na uobičajen svakodnevni kontekst života i običaja ${ }^{1}$.

Već pedesetih godina prošlog stoljeća Jean Danielou govorio je o gostoljubivosti kao o velikoj ljudskoj stvarnosti u smislu „problema” koji se nameće teološkoj refleksiji zbog aktualnosti tadašnjega povijesno-društvenog trenutka. Iako je taj problem odredio kao „problem" za civilno društvo, istodobno je naglasio da je gostoljubivost $u$ svojoj biti kršćanska krjepost, čiji nedostatak koje otkriva površnost kršćanstva, čija stvarnost ne završava na vanjskoj praksi, nego nam se otkriva kao istinski „kršćanski misterij” (mystère chrétien) ${ }^{2}$.

Stranac/tuđinac se, kao i drugost, uvijek definiraju u odnosu na razliku, kao što je to slučaj s kulturnim i vjerskim običajima, no ne smije se zaboraviti da postoje i drugi čimbenici koji potenciraju fenomen stranosti, kao što su ekonomski, socijalni i politički. Gostoljubivost kao antropološki fenomen odnosi se na drugost. Njezino poricanje uvijek poprima oblik nepravde ili nasilja ${ }^{3}$. U tom smjeru idu i zaključci eksperata koji su primijetili kako gostoljubivost „nije igrala vodeću ulogu u tradicionalnom teološko-etičkom rječniku Crkve. Za kršćane općenito ona ostaje marginalna krjepost" ${ }^{4}$.

1 Benedeikt XVI., Enciclika Caritas in Veritate, (29. 6. 2009.), AAS 101 (2009), 641709, 62. Govoreći o fenomenu migracija, Papa kaže da je „to fenomen koji impresionira po broju ljudi koji su uključeni, po društvenim, ekonomskim, političkim, kulturnim i vjerskim problemima koje izaziva, po dramatičnim izazovima koje postavlja nacionalnim i međunarodnim zajednicama”.

2 Usp. J. Daniélou, „Pour une théologie de l'hospitalité”, La Vie Spirituelle, 85 (1951), 339-347.

3 Usp. P. Ricoeur, „Straniero io stesso. Il dovere dell'ospitalità”, Vita e Pensiero, 5 (2013), 39-50.

4 W. Janzen, Old Tetsament Ethics: A Paradigmatic Approach, Westminster/ John Knox Press, Luisville, 1994, tal., prijevod, Etica dell'Antico Testamento. Un approccio paradigmatico, Claudiana, Torino, 2004, 238. 
Tema gostoljubivog prihvaćanja naglašena je kao jedna od temeljnih krjeposti u pokušaju da se skicira cjeloviti oblik ljudskog kao takvog ${ }^{5}$. Definira se kao moralna vrijednost koja je sve potrebnija. Informirati vjerničku savjest o gostoljubivosti kao kršćanskoj krjeposti, zadaća je od primarne važnosti koju Crkva sebi postavlja u trenutnom povijesno-kulturnom kontekstu. Možemo reći da to spada u onaj okvir koji Drugi vatikanski sabor definira kao razlučivanje „znakova vremena”.

Kao stručnjakinja za ljudsko ${ }^{6}$ Crkva ima dugu povijest gostoljubivog iskustva kao temeljne sastavnice svojeg poslanja, iako ne uvijek eksplicitno tematizirane, koja je poniknula kao odgovor vjere na izazove ljudske egzistencije. Kristova spasiteljska prisutnost za Crkvu ostaje glavni hermeneutički ključ gostoljubivog djelovanja kao moralnog dobra koje se prevodi u zapovijed ljubavi prema bližnjemu i dobiva svoje puno značenje polazeći upravo od Isusove osobe.

\section{GostoluUbivost KaO ISkUSTVO teOlogalnOG ŽIVOTA}

\subsection{Kristološki temelj gostoljubivog prihvaćanja}

Objava ima strukturu povijesnog događaja u kojem se gostoljubivost daje izvorno kao iskustveni događaj prožet vjerom. Horizont smisla koji vjera otkriva po gostoljubivom djelovanju pokazuje njegovu strukturalnu cirkularnost. Iskustvo vjere odnosi se na iskustvo gostoljubivosti i obratno: iskustvo gostoljubivosti biblijskog čovjeka upućuje na iskustvo vjere u smjeru recipročne realizacije. Ta cirkularnost naglašava egzistencijalni smisao biblijskog čovjeka. Vjerska i etička vrijednost gostoljubivosti podrazumijeva egzistencijalni odnos s Bogom koji upućuje na moralno djelovanje čovjeka, na njegovu odgovornost. Gostoljubiva dobrodošlica, potvrđena u oba Zavjeta, odnosi se ponajprije na čovjeka u kušnji i potrebi. Ona se uzdiže na kriterij po kojem se procjenjuje 'kvaliteta' vjerskog djelovanja koje se odnosi na teologalnu vezu između Boga i čovjeka, a Bog je svrstava među kriterije vlastite vjerodostojnosti ${ }^{7}$. Ona poprima oblik njegove pravednosti, kao izraz ljubavi, odnosno kao prosudba njegove pravednosti za one unutar religije kao i za one izvan nje. Gostoljubivost

5 G. Vendrame, „Il problema della morale oggi”, Corso di morale, T. Goffi, G. Piana, Vol. I, Queriniana, Brescia, 2004, 33.

$6 \quad$ Usp. Pavao VI, Enciklika Populorum Progressio, (26. 3.1967.), AAS, 59 (1967), 257-299, 13: „iam rerum humanarum peritissima”.

7 Usp. Mt 25, 31-46. 
je predstavljena u Svetom pismu kao univerzalno dostupan dokaz o Božjem otajstvu u obliku predanosti i brige za čovjeka ${ }^{8}$.

Simbolično-stvarno značenje gostoljubivosti nalazi svoj smisao $u$ pozivu na transcendentno otajstvo, tj. na temelj gostoljubivog Boga. Strukturna relacijska dinamika gostoljubivog odnosa daje ljudskoj slobodi, u njezinu prihvaćanju, sposobnost prihvaćanja drugosti. Povjerenje gostoljubivom Bogu, kao obliku vjere/povjerenja, daje se samo u slobodi, to jest $u$ iskustvu koje konstitutivno strukturira moralnost biblijskog čovjeka. U biblijskoj perspektivi ljudsko se ne daje ako nije otvoreno drugosti, ako nije gostoljubivi čovjek; sloboda koja isključuje prihvaćanje blizine drugoga ne podudara se s izvornom nakanom Boga koju nam Sveto pismo potvrđuje. Negostoljubivost se u Bibliji uvijek doživljava kao velika nepravda, podložna Božjem gnjevu. Ona je jedno od ljudskih iskustava koja odražavaju antropološku kompleksnost čovjeka. Iz perspektive vjere ona se uspostavlja kao unutarnja dispozicija otvorenosti prema drugosti i tako postaje povlašteni način posredovanja evanđeoske ljubavi (agápe), kao ispunjenog oblika vjere.

Teologalna kvaliteta gostoljubivosti ovisi o kvaliteti odnosa s Bogom. Biblijska gostoljubivost, kao teološka stvarnost, nije orijentirana isključivo na stvaranje boljeg čovječanstva, nego sama po sebi, intrinzično, usmjerava religiju prema Bogu kao cilju svojega konačnog ispunjenja, upisujući se u stvarnost univerzalnog ljudskog bića kao njegova krajnja istina ${ }^{9}$.

Gostoljubivost je predstavljena kao konstitutivna matrica reda značenja u koju je upisano ljudsko iskustvo naklonosti ${ }^{10}$. Iskustvo gostoprimstva, kao svjedočanstvo vjere, otvara mogućnost da se Gospodin može susresti i prepoznati od bilo koga. Odnos koji je uspostavljen u filokseniji kao oblik skrbi i predanosti, objektivno postavlja subjekt $\mathrm{u}$ odnos $\mathrm{s}$ Gospodinom, gdje ta veza ima nepogrešivu eshatološku vrijednost ${ }^{11}$. Njezino življenje u svjetlu vjere uvijek se konstituira kao svjedočanstvo koje se smatra figurom Božje pravde u obliku otkupljenja od zla. Ona se transkribira kako u obliku bratskog odnosa učenika tako i u međuljudskim odnosima, što se uvijek događa na iznenađujući način: relacija koja, ako je

8 Usp. P. Sequeri, La giustizia dell'agape. L'ago religioso della bilancia, Servitium, Milano, 2010, 6-9.

9 Idem, 30.

$10 \quad$ Idem, 36.

11 Usp. P. Sequeri, L’idea della fede, Glossa, Milano, 2002, 163-164. 
uobličena gostoljubivošću, postaje sposobna ostvariti bratsku solidarnost u svetopisamskom smislu ${ }^{12}$.

Biblijska gostoljubivost ne može se svesti na filantropsku gestu, već uvijek ostaje ponuda Bogu kao znak zajedništva ${ }^{13}$. Prihvaćeni brat, prema Svetom pismu, uvijek je Kristovo proročanstvo. Dva iščekivanja, brat koji dolazi i dolazeći Krist u paruziji, dva su konkomitantna događaja koja potiču moralno djelovanje vjernika. Pismo kaže da je ljudska sloboda kadra otvoriti se bezuvjetnosti koju joj Bog daje, ali i zatvoriti se u svojoj negostoljubivoj samodostatnosti $^{14}$. Kristovo spasiteljsko otajstvo daje se kao temelj zajedništva koje vodi otvorenosti prema drugome i njegovu prihvaćanju, te čini brata odgovornim za potrebe drugoga, pa upravo ondje gostoljubivost poprima oblik skrbi za drugoga ${ }^{15}$.

Kvalitativni profil gostoljubivog odnosa, kao oblik bratske uzajamnosti i bezuvjetne posvećenosti, strukturira kršćansko zajedništvo i otkriva istinu Božje predanosti. Gostoljubivo djelovanje u evanđeoskoj perspektivi potiče/izaziva na obraćenje upravo u snazi istine koja je u njoj upisana kao znak gostoljubivog i pouzdanog Boga, čija je gostoljubivost jedan od niza oblika koje kršćanska ljubav poprima i očituje kao bezuvjetnu predanost ${ }^{16}$.

Moralno djelovanje, in-formirano biblijskom vjerom, naglašava koliko je gostoljubiva dobrodošlica bitna za evanđeosku ortopraksiju, s obzirom na slobodu i odgovornost crkvene zajednice ${ }^{17}$. U tom smjeru ona preuzima važnu ulogu da sačuva zajednicu vjernika od zatvaranja u intimni krug svojih članova, upravo držeći je uvijek otvorenom za mogućnost da susretne samog Krista u osobi siromašnog stranca. Na taj se način u vjerujućoj zajednici otvara sav potencijal svjedočenja preko dara prisutnosti drugoga/drugačijega koji on donosi sa sobom ${ }^{18}$.

Eshatološka dimenzija biblijskog etosa gostoljubivosti nalazi svoju kulminaciju u eshatološkom sudu, gdje teologalna veza doseže svoje ispunjenje $\mathrm{e}^{19}$. Bog počinje širiti svoje kraljevstvo od gostoljubi-

12 Usp. G. Bentoglio, Aperura e disponibilità l'accoglienza nell'epistolario paolino, Editrice Pontificia Università Gregoriana, Roma, 1995, 248.

13 Usp. Fil 4, 10-20.

14 Usp. 2 Kor 6, 1.

15 Usp. Rim 12, 13; Kol 4, 10; 1Tim 3, 2; 5, 10; Tit 1, 8.

16 Usp. P. Sequeri, L'idea della fede, 713-714.

17 Usp. G. Bentoglio, Apertura e disponibilità l'accoglienza nell'epistolario paolino, 240.

18 Usp. S. Bastianel, L. Di Pinto, „Per una fondazione biblica dell'etica”, 160.

19 Usp. Mt 25, 31-46. 
vog prihvaćanja posljednjih kako bi došao do svih ${ }^{20}$. Moralno djelovanje otkriva eshatološku nadu u ispunjavanju volje Očeve kao zapovijed ljubavi. Prema Mt 25 to se događa i izvan kruga Izraela te postavlja svakog čovjeka u odnos s Kristom ${ }^{21}$.

Za novozavjetne spise gostoljubivost postaje povlašten način potpunog življenja ljubavi kao cjelovitog ispunjena kršćanske vjere. Sam se Isus poistovjećuje sa svima onima koji se nalaze u potrebi: „Tko primi radi mene jedno ovakvo dijete, mene prima”22; „Zaista, kažem vam, što god učiniste jednome od ove moje najmanje braće, meni učiniste" ${ }^{23}$, itd. Za njega je to uvijek participativna gostoljubivost koja prihvaćanjem prepoznaje i štiti osobu u njezinu dostojanstvu, gdje je ponuditi sklonište, nahraniti, napojiti samo vanjski znak koji upućuje na unutarnje prihvaćanje drugoga kao moralni čin odgovornosti.

Ovakvo gostoljubivo prihvaćanje, sastavljeno od odnosa koje stvara zajedništvo, nije svedivo na čistu filantropsku gestu prve pomoći ${ }^{24}$, jer biti moralan znači biti gostoljubiv i sa strancem i sa svakim onim kog se susretne na životnom putu ${ }^{25}$. Novi zavjet kontinuirano potvrđuje središnje mjesto gostoljubivog prihvaćanja kao teološke teme u objavi Kraljevstva Božjega ${ }^{26}$. Bezuvjetna gostoljubivost, upućena svima, ističe osobine Isusa koji je često bio u kontekstu gostoljubivog prihvaćanja. Učenici na putu u Emaus prepoznali su ga, nakon uskrsnuća, u jednoj od temeljnih gesta gostoljubivosti - lomljenju kruha s drugima ${ }^{27}$.

Isusovo gostoljubivo djelovanje, njegovo bezuvjetno prihvaćanje postaje ključ za razumijevanje njegove osobe i njegova poslanja, koje sinoptička tradicija jasno naglašava, do te mjere da praksa gostoprimstva postaje kriterij zajedništva s njim i teologalna povezanost koju otkriva gostoprimstvo ${ }^{28}$. Novi zavjet označava odlučujući

20 Usp. S. Bastianel, L. Di Pinto, „Per una fondazione biblica dell'etica”, 167.

21 Usp. K. H. Schelkle, „Escatologia neotestamentaria”, Mysterium Salutis, Nuovo Corso di dogmatica come teologia della storia della salvezza, J. Feiner, M. Lohrer, Queriniana, Brescia, 1978, 242-248.

22 Mt 18, 5.

23 Mt 25, 40-45.

24 Usp. Papinski savjet za pastoral migranta i putnika, Erga migrantes caritas Christi, (3. 5. 2004.), AAS, 96 (2004), 762-822, 37.38.91.

25 Usp. T. W. Ogletree, Hospitality to the Stranger: Dimensions of Moral Understanding, Fortress Press, Filadelfia, 1985, 1.

26 Usp. J. Koenig, New Testament Hospitality: Partnership with Strangers as Promise and Mission, Fortress Press, Philadelphia, 1985, 27.

27 Usp. Mt 11, 28; 22, 1-14; Lk 14, 15-25.

28 Usp. Mt 25, 31-46. 
korak u razumijevanju gostoljubivog prihvaćanja čovjeka u potrebi, u svojoj naraciji specificira motive, utemeljujući gostoljubivo djelovanje $u$ dvostrukom smjeru: kristološkom i eshatološkom ${ }^{29}$.

Kristološki temelj biblijske gostoljubivosti u evanđeljima artikuliran je kao Isusovo bezuvjetno prihvaćanje svakog ljudskog postojanja. Za njega nema dostojnih ili nedostojnih, kako to potvrđuju skandalozni gostoljubivi odnosi s javnim grešnicima koje je Isus prakticirao; ne postoji ljudsko stanje koje nije podložno Božjem otkupljenju, unatoč njegovoj misiji koja se odvija u društvo u kojem je religija pedantno kodificirala ono što je čisto ili nečisto, dostojno ili nedostojno, itd. Ta bezuvjetna gostoljubivost stajala je izvan norme vjerski prihvatljivog djelovanja ${ }^{30}$.

Drugo mjesto u kojem jasno vidimo taj kristološki temelj gostoljubivosti jest odlomak Mt 25, gdje se Isus poistovjećuje s onim koji prihvaća stranca kao da prihvaća njega samog. U kristološkoj perspektivi prihvaćanje stranca postaje prigoda da se živi osobni odnos s Isusom, u provođenju ljubavi (agape) kao ispunjenog oblika vjere, temeljnog zakona kršćanina ${ }^{31}$.

Drugi razlog koji Pismo ističe kao temelj gostoljubivog djelovanja jest eshatološki poredak, i usko je povezan s odredištem čovjeka na vječni život. Svi vjernici u Kristu hodočasnici su i stranci u ovom svijetu, ugošćeni od Boga. Egzistencijalna dimenzija privremenog postojanja na svijetu, ali ne od svijeta, otkriva krajnji smisao kršćanskog postojanja: „Ovdje dolje nemamo stabilan grad, ali tražimo onaj budući." ${ }^{32}$

Gostoljubivost koju Isus prakticira je stav, predispozicija subjekta koja u sebi u potpunosti uključuje odgovornost prema drugima i postaje performativna akcija koja radikalno mijenja strukturu ljudskih odnosa. Gostoljubivi subjekt, koji prihvaća druge, postaje sveukupna figura odgovornosti, prema izvornoj Božjoj nakani koja se očituje u Isusovu djelovanju, a antropologija biblijskog gostoprimstva postaje konstitutivna za samo kršćansko poslanje u uspostavi kraljevstva koje je inaugurirao Isus ${ }^{33}$.

29 Usp. S. Leone, „Le radici teologiche dell'hospitalitas”, Vita Monastica, 233 (2006), 70-71.

30 Usp. B. Chilton, J.J.H. McDonald, Jesus and the Ethics of the Kingdom, Erdmans Publishing Co. Grand Rapids, 1987, 96.

31 Usp. Mt 7, 12; Mk 12, 31.

32 Usp. Heb 13, 14; 11, 10-16.

33 Usp. W. Janzen, Etica dell'Antico Testamento. Un approccio paradigmatico, 241242. 
Biblijska gostoljubivost, kao moralno iskustvo u vjeri, svjedoči o zajedništvu s Bogom i, počevši od nje, biblijski čovjek pokušava uspostaviti međuljudske odnose. Prianjanje vjere u odnosu na etičku vrijednost gostoljubivosti mora uvijek uzeti u obzir kulturno posredovanje njezine vrijednosti. Razlika između povijesnog razumijevanja vrijednosti gostoprimstva, koje pripada kulturi koja je povijesno daleko od nas, korigira se preko memoria Jesu, interpretativnog sjećanja Gospodina u povijesnom kontekstu, u egzistencijalnoj situaciji koja je ponekad radikalno drugačija u odnosu na onu Isusovu. Biti prihvaćen/ugošćen od Boga i prihvatiti/ugostiti brata dvije su strane teologalne veze koja uspostavlja smisao i svrhu vjerske odgovornosti gostoljubivoga biblijskoga gostoprimstva koje nalazi svoje ispunjenje u etičkoj praksi. Pismo nam neprestano potvrđuje da biblijsko gostoprimstvo kao odgovoran oblik djelovanja izražava u potpunosti intencionalnost Božjeg djelovanja po Isusovom gostoljubivom stilu ${ }^{34}$.

\subsection{Biblijska krjepost}

Biblijsko poimanje antropološkog fenomena gostoljubivosti kao izvornog ljudskog iskustva temeljna je točka u razumijevanju njezine moralne dimenzije. Događaj gostoljubivosti koji se daje u singularnom kristološkom događaju navješćuje nečuvenu Božju bliskost čovjeku te iziskuje njegovo samoodređenje koje se očituje u bezuvjetnom gostoljubivom prihvaćanju drugoga $u$ vjeri.

Izdvajajući biblijski fenomen gostoljubivosti, njegove društvenopovijesne forme kao iskustva dobra koje uključuje njezinu specifičnu antropološku vrijednost, gdje Pismo preuzima ovo ljudsko u svojoj vrijednosti kao dobro i istinu ${ }^{35}$, nalazimo se suočeni s moralnom dimenzijom biblijske objave, koja se ne može u potpunosti poistovjetiti sa samim društvenim običajem gostoljubivosti, premda je to njezin nezaobilazni čimbenik, koji upućuje na njezin temelj, na besplatnost (dar) gostoljubivog Boga, koji uspostavlja poseban biblijski etos ${ }^{36}$. Taj biblijski etos u svojim prioritetima između povijesne sadašnjosti i eshatološke budućnosti ubacuje skrb o međuljudskim odnosima, usredotočenima na uzajamno prihvaćanje kao slobodan dar koji uvijek upućuje na odnos s Bogom i koji usavršava cijeli ljudski život,

34 Usp. S. Bastianel, Sulla formazione morale. Soggetti e itinerari, Ed. Il Pozzo di Giacobbe, Trapani, 2013, 41-44.

35 Usp. Fil 4, 8.

36 Usp. M. Chiodi, Teologia Morale Fondamentale, Queriniana, Brescia, 2014, 209-213. 
kao krjepost zajedništva: što je konstitutivni habitus kršćanskog života.

Božja blizina, koju Isusovo gostoljubivo prihvaćanje otkriva, uspostavlja blizinu kao temeljnu moralnu instancu i tumači je ne kao pasivnu činjenicu, nego kao aktivnu inicijativu slobode. Gostoljubivost traži odluku onih koji djeluju i u gostoljubivoj relaciji otkriva dobro koje upućuje na njezin temelj. Ovdje norma proizlazi iz relacije koju uspostavlja odnos između vjere i morala, djelovanje $u$ vjeri koje se temelji na preventivnom Božjem djelovanju. U praktičnoj odluci gostoljubivog djelovanja čovjek potvrđuje da prihvaća dar koji ga je preduhitrio ${ }^{37}$.

Sveto pismo svjedoči o gostoljubivoj dobrodošlici kao o dobru koje snažno kvalificira moralno iskustvo biblijskih međuljudskih odnosa, u okviru Božjeg poziva na življenje zajedništva s njim. Pismo nam daje razloge i unutarnju dinamiku tog izvornog ljudskog djelovanja usmjerenog na teološki poredak kao točku njegova ispunjenja, otvarajući smisao odnosa između cilja i dobra, između Božje stvarnosti, koja uspostavlja zajedništvo s ljudskom osobom, i njezinog istinskog temelja ${ }^{38}$.

U biblijskom gostoljubivom djelovanju čovjek ostvaruje odnose koji ga strukturiraju, angažirajući njegovu slobodu i odgovornost u zahvalnom odgovoru kao moralnoj odluci ${ }^{39}$. U potpunosti poistinjuje prirodu subjekta kao strukturno relacijskog čovjeka, gdje njezina negacija uklanja pretpostavke vlastite mogućnosti; otuda $i$ smisao biblijske imperativnosti da se ne zaboravlja gostoljubivost kao konstitutivna dimenzija ekonomije spasenja ${ }^{40}$. Pismo otkriva onaj horizont smisla koji je upisan u gostoljubivu dobrodošlicu, kao bezuvjetnu blizinu Boga, iz koje proizlaze moralna pitanja o tome kako živjeti i što učiniti kako bi se živio život dostojan čovjeka i imao dobar odnos s Bogom.

Gostoljubiva dobrodošlica kao čovjekov stav (habitus vitae) prema Svetom pismu predisponira vjernika u potrazi za njegovim ciljem ${ }^{41}$; kao moralna krjepost ona je plod izbora pojedinca, koji otkriva svoje mogućnosti kroz slobodu, naglašavajući tu vezu

37 Idem, 302-307.

38 Usp. Aristotele, Metaphysica, I, 2, 982,b 6ss; T. Akvinski, Summa Theologica, I-II, q1, a 1-8.

39 Usp. D. Abignente, S. Bastianel, Sulla formazione morale. Soggetti e itinerari, Ed. Il Pozzo di Giacobbe, Trapani, 2013, 7.

40 Usp. Heb 13, 2.

41 Usp. A. MacIntyre, Dopo la virtù. Saggio di teoria morale, Feltrinelli, Milano, 1981. 
između vjernika i njegova cilja, to jest njegova zajedništva s Bogom ${ }^{42}$. Taj odnos s Bogom, koji biblijsko gostoprimstvo nosi u sebi, plod je usklađenosti s njegovom riječi u poslušnosti njegovoj volji ${ }^{43}$.

Gostoljubivost predstavlja ljudsku instancu koja je racionalno definirana; ponovno iščitana u perspektivi vjere ili kraljevstva koje je uspostavio Isus iz Nazareta, ona otvara nov i neviđen horizont smisla, koji je sposoban radikalno transformirati vjerničku savjest s obzirom na odgovornu brigu da se bude bližnji. Taj unutarnji stav, kao otvorenost i dostupnost u evanđeoskoj perspektivi, strukturiran je kao habitus vitae, koji daje subjektu slobodu i odgovornost da se uvijek odluči za dobro drugoga, do te mjere da se izgubi u korist drugih.

\section{GostoluUbivost u FILOZOFSKOM DISKURSU}

\subsection{Hermeneutski okvir propitivanja teme gostoljubivosti}

Postmoderna egzistencijalna sfera ${ }^{44}$, obilježena brojnim društvenim post-sekularnim fenomenima ${ }^{45} \mathrm{u}$ konstantnoj promjeni, nastavlja s postavljanjem pitanja smisla o svemu što je konstitutivno ljudsko. Radikalne preobrazbe i kulturne fragmentacije pridonijele su slabljenju samorazumijevanja i identiteta postmodernog subjekta koji više ne crpi smisao iz velikih naracija kako bi oblikovao etos sposoban informirati intersubjektivne relacije. U tom antropološkom okviru postoji i pitanje gostoljubive recepcije drugoga, različitog, kog se često doživljava kao stranca; ono je postalo jedno od glavnih čimbenika koji potiču današnju javnu raspravu. Indeks relevantnosti koji se pridaje važnosti teme gostoljubivosti od strane suvremene filozofski misli, proporcionalan je krizi tog samorazumijevanja subjekta postmoderne ere, zbog niza antropoloških i filozofskih čimbenika ${ }^{46}$.

\footnotetext{
$42 \quad$ Usp. Mt 25, 35.43.

43 Usp. X. Leon-Dufour, "Virtù e vizi,,, Dizionario di Teologia Biblica, Marietti, Torino, 1978, cc. 1381-1384.

44 Usp. J. F. Lyotard, La condizione postmoderna, Feltrinelli, Milano, 1981; Z. Bauman, Il disagio della postmodernità, Bruno Mondadori, Milano, 2002.

45 Usp. A. Patriarchi, A. Vinale, Per una critica della secolarizzazione, Aracne, Roma, 2009; „Oltre la secolarizzazione”, Credere oggi, 176 (2010), 3-130; Ch. Taylor, L'età secolare, Feltrinelli, Milano, 2010.

46 Usp. Z. Bauman, La società dell'incertezza, Il Mulino, Bologna, 1999.
} 
Sve se to neizbježno odražava i na crkveni život i utječe na njegovu misiju evanđeoskog svjedočanstva. Gostoljubivu dobrodošlicu, kao neotuđivu svjedočku osobinu, treba kontinuirano specificirati kako bi se prepoznao evanđeoski gostoljubivi stil u njezinoj moralnoj dimenziji u smislu odgovornosti i brige prema toj iznenađujućoj blizini koja postaje mjerom svakog moralnog djelovanja. Teologalni temelj gostoljubivosti, koji smo identificirali u njegovim bitnim značajkama, pruža nam potreban okvir istog teološkog razloga koji vodi dijalogu s filozofskim shvaćanjem čovjeka kao konstitutivnog za življenje same vjere ${ }^{47}$.

Kada govorimo o gostoljubivosti, filozofska literatura svjedoči o izrazima kao što su „konstitutivni”, ,izvorni”, itd., u pokušaju tematizacije i razumijevanja fenomena gostoljubivosti kao antropološki konstitutivnog. Konkretizacija intersubjektivnog odnosa jedna je od temeljnih tema koja i dalje propituje suvremenu filozofsku refleksiju. Ona ne tematizira identitet subjekta kao već definiran (dan) prije njegova odnosa s drugima, nego, polazeći od njegovog strukturiranja u intersubjektivnom odnosu, pronalazi mogućnost samog njegovog promišljanja. Ovakav pristup u osnovi se usredotočuje na stavljanje u središte promišljanja intersubjektivnosti, kao konstitutivno antropološkog, što nam omogućuje da razmišljamo o osobnom identitetu čovjeka kao o bitku-u-vezi. Ta se intersubjektivnost predstavlja kao izvorna dimenzija subjekta i kao takva konstitutivna za etičko ${ }^{48}$.

Prvo određivanje tih bitnih koordinata determinira okvir konteksta u kojem se filozofska refleksija o gostoljubivosti umeće kao paradigma ljudskog odnosa shvaćenog kao konstitutivna otvorenost prema drugosti u obliku skrbi i dara. Sada već možemo postaviti temeljno pitanje: kako je gostoljubivost, kao oblik intersubjektivnosti, etički određena? Temeljni stav gostoljubivog odnosa ostaje otvorenost prema drugome, gdje se ego susreće s drugim, u kojem ovo otvaranje dobrodošlice subjekta postaje mjesto slobode koje se određuje kao odgovornost (briga) za drugog. Fenomen gostoljubivosti ostvaruje i tumači čovjeka kao subjekt u odnosu na drugost, na strukturiranje ljudskih odnosa kao temelj etike, gdje ovo ljudsko pronalazi svoje puno ostvarenje. Hermeneutika gostoljubivog prihvaćanja kao oblika ljudskog otvara put za promišljanje o moralnom djelovanju čovjeka u onim oblicima koji ga najviše determiniraju u odnosu na njegove generičke predodžbe; ona nam označuje i resti-

47 Usp. M. Epis, „Teoria dell'esperienza e forma veritativa della fede”, Teologia 36 (2011), 93- 108.

48 Usp. M. Ivaldo, „Intersoggettività come relazione etica”, Aquinas, 28 (1984), 3-4. 
tuira egzistencijalnu istinu gostoljubivosti, njezin smisao i njezin identitet.

Gostoljubivost se uvijek mora tematizirati i nanovo razumjeti zajedno s analizom svoje suprotne stvarnosti, tj. sa zatvaranjem subjekta prema drugome. Osporavajući gostoljubivi prijem, čovjek se izlaže riziku da njegova djela poprime oblik nasilja (filoksenija - ksenofobija), i upravo iz te mogućnosti, povijesno potvrđene, u suvremenoj filozofiji nastaje geneza potrebe razraditi sustavno razmišljanje o gostoljubivom čovjeku.

Želimo odmah istaknuti da je razmišljanje o odnosu prema drugosti kao nepripadnosti uglavnom koagulirano oko lika stranca kao sintetičke i simboličke figure na koju su se kroz povijest refleksije predlagali različiti etičko-filozofski pristupi. S jedne strane nalazimo razmišljanja koja teoretiziraju strukturalno konfliktni karakter intersubjektivnih odnosa kao izvorno ljudskog. U ovu struju spada antropološka perspektiva Thomasa Hobbesa, za koju je ljudska priroda (zamišljena samo u materijalističkom smislu) izvorno sklona konfliktu i sukobu, i gdje sukob postaje temeljni odnos s drugim od svojeg nastanka kao strukturalni dio čovjekova identiteta ${ }^{49}$. Bez prisutnosti protivnika, prema Hobbesu, subjekt ne bi razumio svoj pravi identitet. Stoga rat postaje neizbježna stvarnost kao rješenje sukoba među narodima (priroda čovjeka je bellum omnium contra omnes) ${ }^{50}$.

Kritičko promišljanje moderne, a posebno Immanuela Kanta, koji polazi od Hobbesovih pretpostavki antropologije koja je prirodno sklona sukobu, ostavilo nam je početne pokušaje razmišljanja o uvjetima za trajni mir, i u tom kontekstu također nedovršeni sažetak o gostoljubivosti drugoga/različitog ${ }^{51}$.

Kantova kritička filozofija promišlja univerzalno pravo na gostoprimstvo. U svom djelu Vječni mir (1795.), on identificira, uz druga „ljudska javna prava” kao transcendentalno stanje univerzalnog društva, i pravo na Hospitalität $t^{52}$. On se suočava s pitanjem prava na univerzalno gostoprimstvo u kontekstu kolonijalne ekspanzije svjetskih sila, ponekad nasilne i negostoljubive, gdje nije više stranac taj koji posjećuje našu zemlju, nego kolonijalne sile napadaju zemlju drugih da bi dominirale i iskorištavale. Njegov glavni napor

49 Usp. T. Hobbes, Leviatano, Bompiani, Milano, 2004, 203.

$50 \quad$ Usp. T. Hobbes, De Cive, Le Monnier, Firenze, 1967, 28-29.

51 Usp. U. Curi, Straniero, Raffaello Cortina Editore, Milano, 2010, 106-119.

52 Usp. I. Kant, Per la pace perpetua, Feltrinelli, $22^{\circ}$ ed. Milano, 2016, 65-68. 
promišljanja usmjeren je na to da pokaže kako to pravo vrijedi $\mathrm{u}$ cijelom svijetu, bez obzira na društvene ili geografske granice ${ }^{53}$.

Njegovo promišljanje postavlja gostoljubivost kao instancu obvezujućeg moralnog prava da oni koji se nalaze u tuđoj zemlji, na zemlji drugog, budu tretirani na prijateljski način. Tako za Kanta gostoljubivost postaje konstitutivni element univerzalnog mira zajamčenog zakonom (državom). Prema Kantu, to pravo odgovara dužnosti stranca da poštuje zakone zemlje domaćina. Kantovska slika razlikuje Besuchsrecht i Gastrecht; prvi je pravo pristupa (Besuchsrecht), koje regulira ponašanje stranca u zemlji koja ga ugošćuje i odnosi se na određenu životnu situaciju, u određenom smislu, ograničeno samo na određeno razdoblje. Drugo je pravo na gostoprimstvo (Gastrecht), izvedeno iz zajedničkog posjeda zemlje od strane svih ljudi koji ondje žive ${ }^{54}$.

Kantovska analiza duguje Hobbesovoj perspektivi koja polazi od uvjerenja da je ljudska priroda izvorno i intrinzično ratnička, tako da u svojem racionalnom ishodu trajni mir (ewiger Frieden) svoju stabilnost pronalazi prije svega na pravnoj osnovi, a ne na neprekidnom humanitarnom poticanju - kako on sam kaže, ovdje nema govora o filantropiji, nego o pravu ${ }^{55}$ - tako da bez pravde nije moguć mir. Kantovski projekt na potpuno nov i originalan način uključuje gostoljubivost $\mathrm{u}$ općoj perspektivi trajnog mira kao njegov prijeko potreban uvjet: poštivanje gostoprimstva prema strancima na vlastitom teritoriju, kao što je odsutnost nasilnog ponašanja prilikom posjećivanja teritorija drugih ljudi; oni su za Kanta temeljni elementi za kozmopolitski mir i novi međunarodni poredak potencijalno bez sukoba ${ }^{56}$.

Za Carla Schmitta, , politologa doba nihilizma”, kako ga definiraju $^{57}$, stranac je, kao figura drugosti, uvijek potencijalni neprijatelj (hostis), a neprijateljstvo je primarni intersubjektivni odnos. Drugost je uvijek izvor sukoba i napetosti za intersubjektivni odnos. Za njega, drugost poprima dvije moguće figure: unutarnji konkurent (inimicus) i vanjski neprijatelj (hostis), dva oblika drugosti kao alternativa identitetu subjekta. Ovdje odnos prema drugosti poprima lik nepri-

53 Usp. T. Scappini, Ospitalità/Gastlichkeit, L. Bottani, T. Scapini, Edizioni Mercurio, Vercelli, 2010, 15.

54 I. Kant, Per la pace perpetua, 65; D. Harth, „Per una teoria critica dell'ospitalità”, Ospitalità/Gastlichkeit, L. Bottani, T. Scappini, 22-23.

55 I. Kant, Per la pace perpetua, 65.

56 Usp. U. Curi, Straniero, 120.

57 Usp. L. Mistrorigo, „Carl Schmitt politologo dell'età del nichilismo”, Studium, 81 (1985), 593-603. 
jateljstva koje strukturira i definira vlastiti identitet ${ }^{58}$. Za Schmittovo promišljanje to postaje temeljno pitanje (tko je moj neprijatelj?), kako bih dao konture vlastitom identitetu i razumio tko sam: zato što je neprijateljstvo drugoga kontrapunkt koji određuje i oblikuje moj identitet. Dakle, ne gostoljubivost dobrodošlice, nego neprijateljstvo postaje proces uzajamnog priznavanja, strukturirajući element identiteta subjekta ${ }^{59}$.

Potrebno je spomenuti još jedan važan element za postavljanje ispravne hermeneutike pitanja drugosti i gostoljubivog odnosa u postmoderni, a odnosi se na nihilistički ishod postmodernog subjekta, što predstavlja dijagnozu koja se daje onom stavu koji obezvrjeđuje bilo koji sustav vrijednosti u odnosu na krjepost i gdje svaki oblik htjenja postaje volja za moći. U tom kontekstu subjekt se smješta u središte, a iz tog primata koji mu filozofija dodjeljuje, tek se naknadno, očituje mogućnost strukturiranja vlastitog relacijskog identiteta ${ }^{60}$.

Tematizacija radikalnih uvjeta slobode subjekta, kako je shvaćena od strane postmoderne, dovodi ga do moralne samoće ${ }^{61}$ te uvjetuje isto posredovanje u shvaćanju smisla gostoljubivog prihvaćanja drugosti kao iskustvo odgovornosti i slobode u smjeru moralnog problema, kao i razumljivost same njezine manifestacije. Međuljudski odnos temeljno je obilježen sumnjom i nepovjerenjem prema drugom, do te mjere da se različiti oblici nasilja smatraju radikalnim oblikom zatvaranja subjekta prema drugosti ${ }^{62}$. Sve to naglašava poteškoću nihilističke misli da promišlja o gostoljubivu čovjeku kao nečem izvornom, a koja prethodi bilo kakvoj mogućoj definiciji njega u odnosu na čin u kojem on postaje dostupan drugome.

Odnos prema drugosti u smislu strukturalno konfliktnog intersubjektivnog odnosa nije jedini mogući put u njezinom promišljanju. To predstavlja dio filozofske refleksije koja je određena konfliktnim povijesnim kontekstom u kojem se pokušalo pronaći razloge za trajno nasilje intersubjektivnih relacija. Sukob (negostoljubivost) više se ne smatra nužnošću, nego jednom od potencijalnih

58 Usp. C. Schmitt, „Il concetto di 'politico”, Le categorie del 'politico', G. Miglio e P. Schiera, il Mulino, Bologna, 1972, 91-116.

59 Usp. C. Schmitt, Ex Captivitate Salus. Esperienze degli anni 1945-74, Adelphi, Milano, 1987, 91.

60 Usp. U. Regina, „Figure della libertà postmoderna”, Soggetto e libertà nella condizione postmoderna, F. Botturi, Vita e Pensiero, Milano, 2003, 41-45.

61 Usp. Z. Bauman, Postmodern Ethics, Blackwell, Oxford-Cambridge, 1993, 53 ss.

62 Usp. J. S. Mill, Sulla libertà, Sugarco Edizioni, Milano, 1990, 97 ss. 
mogućnosti subjekta; u osnovi je ishod njegovog zatvaranja drugosti. Odnos prema drugome/različitome više se ne doživljava isključivo kao izvor sukoba, a intersubjektivni odnos između dvije drugosti počinje se oblikovati kao otvarajući odnos koji uključuje subjekt u njegovu odgovornost prema iznenađujućoj blizini.

Pokušavajući racionalno produbiti razloge fenomena neprijateljstva prema drugome, promišljanje Jacquesa Derride usredotočeno je na ksenofobiju i neobuzdanu negostoljubivost prema drugosti kao stranosti u različitim oblicima koje ona može poprimiti. Sve to ga navodi da produbi stvarnost filoksenije i da etiku gostoprimstva promišlja kao izvorno stanje čovjeka ${ }^{63}$. Derrida kritizira teoretski Kantov pristup gostoljubivosti, koji bi, prema njegovim riječima, bio gostoljubivost paternalističkog oblika, u kojem bi ipseita diktirala pravila gostoprimstva ${ }^{64}$. Takav pristup ga navodi na teoretiziranje bezuvjetnog, apsolutnog i prethodnog gostoprimstva u odnosu na bilo koju zakonsku kodifikaciju. Za Derridu svaki pokušaj da se ograniči gostoljubivost, budući da je ona temeljni moralni zahtjev svakog čovjeka, konfigurira se kao nepravda, tako da se po njemu ne govori više o pravu na gostoprimstvo (kao ograničavajući čin, limitiran na određene egzistencijalne dimenzije), nego o etici gostoljubivosti, to jest o radikalnom i bezuvjetnom gostoprimstvu ${ }^{65}$.

Odnos gostoljubive dobrodošlice jedan je od načina odnosa s drugima koji se ne može svesti samo na poštivanje i toleranciju različitosti, što bi i dalje održalo tu nepremostivu udaljenost (i nepovjerenje), jer ona se uvijek konfigurira kao otvaranje subjekta drugosti, kojoj oblik daje biblijsko svjedočanstvo. Od samog početka ona se očituje kao bezuvjetni čin skrbi i posvećenosti drugome, kao odgovor na njegov apel. Ono što je biblijska objava sačuvala kao 'zalihu smisla' u promišljanju prihvaćanja drugog, filozofija je, ne bez poteškoća i vrlo kasno, preuzela kao put koji je vodi do propitivanja gostoljubivosti kao izvorno ljudskog. Susret s drugim uvijek ima uvijek formu događaja u kojem se 'ja' dovodi pred nekoga tko je stran i različit ${ }^{66}$. Taj događaj susreta u kojem se daje međuljudski odnos, otvara niz etičkih pitanja. Kako moralno odrediti pravu relaciju u odnosu između 'ja' i 'drugosti'? Koji oblik pravde treba promišljati $\mathrm{u}$ intersubjektivnom odnosu? To su samo neka od pitanja koja se još jednom postavljaju pred suvremenu filozofsku refleksiju koja

63 Usp. J. Derrida, Sull'ospitalità, Baldini e Castaldi, Milano, 2000.

64 Idem, 128.

65 Idem, 83-84.

66 Usp. B. Casper, Rosenzweig e Heidegger. Essere ed evento, Morcelliana, Brescia, 2008, 47. 
se nastoji suočiti s pojavom neprijateljstva/negostoljubivosti, kao oblikom intersubjektivnog odnosa, i ponovno se zapitati o egzistencijalnim razlozima subjekta koji generiraju oblike negostoljubivosti do te mjere da postanu djela nasilja bez presedana koje nam povijest neprestano potvrđuje. Ono što je do sada rečeno pronalazi svoju sintezu u pitanju: zašto nasilni i negostoljubivi čovjek?

\subsection{Dar i skrb za druge}

Tema gostoljubivosti u filozofiji pokazuje svu njezinu teorijsku složenost, koja je svojstvena konstitutivnim strukturama ljudskoga. Ona predstavlja topos koji se odnedavno analizira sa sve većom revnošću, ne samo s obzirom na praktične hitnosti ljudskog suživota nego i da bi se shvatio duboki smisao ljudskog bića kao otvorenosti prema drugome. Gostoljubiva dobrodošlica tema je koja se uglavnom promišlja u odnosu na različita lica drugosti, polazeći od stranosti vlastitog 'ja', te prolazi kroz drugost 'tu', i konačno se odnosi na tuđinu 'trećeg'. Ona se manifestira kao fenomen ljudskog koji slijedi različite antropološke registre koji su međusobno povezani.

Naše pitanje, s kojim smo propitivali ovaj fenomen u filozofskoj sferi, upravo je etičko, koje se odnosi na slobodu i odgovornost subjekta koji se uspostavlja u gostoljubivom odnosu. Problematična priroda gostoljubivog prihvaćanja, u svojim višestrukim izrazima unutar intersubjektivnih odnosa, očituje se od same zore zapadne civilizacije koja je kodificirala moralne norme kako bi zaštitila goste od svih oblika koje bi negostoprimstvo moglo poprimiti. Prepletanje značenja koja čine fenomenalnu stvarnost gostoljubive dobrodošlice pripada izvornom identitetu subjekta, u njegovoj konstitutivnoj otvorenosti prema drugom kao temelju svakog mogućeg odnosa. To je stvarnost koja se odnosi na ontološki temelj subjekta i koja učvršćuje ljudsko s njegovom izvornom razinom.

Gostoljubivi odnos uvijek u sebi nosi konstitutivnu ambivalenciju koja je svojstvena odnosu hostis-hospes. Ta se ambivalentnost prevladava u perspektivi prepoznavanja drugosti u onoj izvornoj asimetriji koja vodi do reciprociteta, gdje se razlike čuvaju, a ne uništavaju. Ovakav postupak naglašava gostoljubivost dobrodošlice kao univerzalnog primjera priznavanja drugosti ${ }^{67}$ : gostoljubivost je upravo ona antropološka instanca koja bi svakom čovjeku jamčila

67 Usp. D. Harth, „Per una teoria critica dell'ospitalità”, Ospitalità/Gaslichkeit, L. Bottani e T. Scappini, Edizioni Mercurio, Vercelli, 2010, 21. 
da ne bude primljen na negostoljubiv način $u$ intersubjektivnom odnosu $^{68}$.

Subjekt gostoljubivog djelovanja, prije bilo kakvog pokušaja kodificiranja njegova stava, odnosi se na praksu gostoprimstva unutar egzistencijalnog okvira. Sve to počinje u ljudskoj savjesti, koja je strukturirana kao otvaranje drugome u obliku gostoljubive dobrodošlice. To dovodi do razumijevanja gostoljubivosti kao etike svakodnevne prakse, gdje apel zakona, tek naknadno, pomaže da bi se živjela kao etika gostoljubivosti u odnosu na pravdu. Gostoljubivost postaje povlašteni prostor za promatranje slobode kao načina na koji se subjekt odnosi prema drugima, u procesu uzajamnog priznavanja. U našem slučaju, sloboda u intersubjektivnom kontekstu konstituirana je kao odgovornost za drugug69, ona postaje odgovor na apel drugoga i tako decentralizira subjekt i konfigurira se kao otvaranje ${ }^{70}$. Odlučiti se za drugoga u gostoljubivom prihvaćanju znači stavljanje u relaciju dobra s nesvodljivošću lica koje je prihvaćeno u njegovoj drugosti koje „ne ograničava, nego promiče moju slobodu, rađajući moju dobrotu ${ }^{71}$ ”.

Dobro koje se daje u gostoljubivom prihvaćanju sudjeluje u intersubjektivnom odnosu i objašnjava posebnost drugoga koji se izražava u brizi, balansirajući drugu instancu, onu o univerzalnosti pravde (Kantova instanca), kao jamstvo uzajamnosti prema bilo kome. Simetriju pravednoga i asimetriju dobra propitivali su Lévinas i Ricoeur, gdje za Lévinasa trajektorij polazi od simetrije pravde kako bi se došlo do njezine realizacije u asimetriji dobra, dok je Ricoeur pokušao uravnotežiti potrebu za pravdom i dobrom/ljubavlju za svoju antropološku radikalnost ${ }^{72}$.

Gostoljubivost kao odgovornost za druge ima snažnu crtu slobodnog dara koji proizlazi iz slobode htjenja, koje se javlja na intencionalnom horizontu. Prakticiranje gostoljubivosti stavlja onoga tko je prima u središte i uspostavlja odnos s ciljem postizanja dobrobiti drugih. Besplatnost proizlazi iz slobode izbora i poprima oblik iznenađenja koje proizlazi iz konstitutivne subjektivnosti i vraća nam smisao gostoljubivosti kao dara i brige. Gostoljubiva gesta je

68 Usp. I. Kant, Per la pace perpetua, 65-68.

69 Usp. E. Lévinas, Fuori dal soggetto, Marietti, Genova, 1992, 34.

70 Usp. F. Riva, „Intersoggettività e figura della libertà”, Soggetto e libertà nella condizione postmoderna, F. Botturi, Vita e Pensiero, Milano, 2003, 200-201.

71 E. Lévinas, Totalità e infinito, 302.

72 Usp. F. Riva, Il bene e gli altri. Differenza, universale, solidarietà, Vita e Pensiero, Milano, 2007, 145-147; P. Ricoeur, Amore e giustizia, Morcelliana, Brescia, 2000. 
gesta izvorne otvorenosti prema drugom, gdje je drugi ugošćen u svom intencionalnom svijetu. Gostoljubivi odnos postaje izlaganje drugome sa sviješću o sebi kao slobodnom koji je otvoren prema drugima, što je i sam preduvjet da se gostoljubivost dogodi (Ricoeur). Dinamika gostoljubivog odnosa polazi od dispozicije subjekta bića-za-drugog, to jest kretanja sopstva prema drugom, čemu slijedi drugi pokret gostoljubivog odnosa, koji dovodi drugog do sebe. Samo stvarna dostupnost subjekta prema drugom jamči gostoljubivi odnos ${ }^{73}$. Dar odnosa „daje čovjeku ljudski smisao”, a ljudska kvaliteta odnosa uvijek poprima oblik dara ${ }^{74}$.

Gostoljubivost kao besplatnost ne zahtijeva nikakvu razmjenu, iako do njezina ispunjenja dolazi tek kada je priznata kao dar drugoga, u trenutku kada se postigne uzajamno intersubjektivno priznanje (Ricoeur). To je otvaranje slobode prema drugoj subjektivnosti koja poprima oblik odgovornosti. Gostoljubiva veza kao zahvalnost, izvorni smisao koji prati primljeni dar (za razliku od ugovora) ${ }^{75}$ otvara očekivanje i nadu ${ }^{76}$.

Priznanje kao zahvalnost postaje odgovor na primljeni dar, kojim se uspostavlja asimetrična uzajamnost ${ }^{77} \mathrm{u}$ intersubjektivnom odnosu (reconnaissance $\mathrm{u}$ dvostrukom rikouerijskom smislu) ${ }^{78}$. Ta vrsta asimetrične uzajamnosti u gostoljubivom odnosu ne zahtijeva uzajamnost, nego favorizira nastavak odnosa između uključenih subjekata. Prihvaćanje kao dar (slobodno utemeljena/darivana veza), to jest izlaganje sebe drugom, potiče subjekt da se brine o drugima ${ }^{79}$. U prihvaćanju dara gostoljubivosti drugost također daje smisao sličnosti i različitosti drugog (odnos dviju sloboda). U gostoljubivom odnosu uspostavljena je intersubjektivna veza koja istodobno predstavlja identitet subjekata u odnosu ${ }^{80}$.

Dvostruko značenje gostoljubivosti (aktivnog/prihvatiti i pasivnog/biti prihvaćen) uokviruje egzistencijalnu dimenziju čovjeka kao

73 Usp. S. Zanardo, Il legame del dono, 545-550.

74 Usp. P. Sequeri, L'umano alla prova. Soggetto, identità, limite, Vita e Pensiero, Milano, 2002, 129-131.

75 Usp. P. Gilbert, ”Gratuité,, Nouvelle Revue de Théologie, 127 (2005), 260.

76 Usp. S. Zanardo, Il legame del dono, Vita e Pensiero, Milano, 2007, 553-557.

77 Usp. P. Ricoeur, Parcours de la reconnaissance. Trois études, Stock, Paris, tal. Prijevod, Percorsi del riconoscimento, Raffaello Cortina Editore, Milano, 2005, 248.

78 P. Ricoeur, Percorsi del riconoscimento, 271-272.

79 Idem, 597.

80 Idem, 601. 
prihvaćenog/ugošćenog u postojanje ${ }^{81}$ i kao pozvanog da ugosti drugoga. Levinas je jasno istaknuo tu izvornu pasivnost subjekta gdje je odgovornost, koja se konstituira u dijakronijskom vremenu kao briga o drugom, postaje lik gostoljubive etike, kao odgovorna blizina koja čuva drugost/različitost subjekta u svojoj radikalnoj razlici izbjegavajući bilo kakav pokušaj fuzije ${ }^{82}$. Briga o drugome konstitutivna je za gostoljubivost, to je dimenzija koja dodatno precizira moralni lik gostoljubivosti, kao zadaća čuvanja različitosti drugih, u kojem se događa decentralizacija subjekta koji se otvara drugom ${ }^{83}$.

Etički prihvatljiv stav uzima u obzir u svojoj odluci prisutnost drugog u njegovoj drugosti, njegov svijet života koji je različit od mog. To je stav koji se ističe kao čin koji ima zadatak prilagoditi razlike i napraviti prostor za slobodu drugih. Njegova performativna dimenzija nalazi se u relaciji (dijalogu) između dviju subjektivnosti kao posredovanja recipročnog otvaranja gdje se nadvladava napetost između drugosti kao stranosti (identitet - drugost/različitost).

Na kraju možemo zaključiti da etika gostoljubivosti ima potencijal postati oblik univerzalne blizine koja se, u relaciji uzajamnog samopriznavanja, profilira kao djelovanje otvoreno svim izazovima drugosti i različitosti koje ljudsko (umano) može poprimiti i kao moralni odgovor na svaki pokušaj zatvaranja subjekta (ksenofobija, rasizam i druga lica koje negostoljubivost može poprimiti), kada se suočava s drugim kao s tuđincem ${ }^{84}$.

\section{MORALNI HORIZONT KRŠĆANSKE GOSTOLJUBIVOSTI}

Gostoljubivost konfigurira ljudsko, kako zbog svoje sposobnosti da uspostavi vezu s Bogom (u svojoj teologalnoj dimenziji), tako i zbog svojih etičkih posljedica u intersubjektivnim odnosima (kao moralni zahtjev). U biblijsko-filozofskoj analizi ona nam je restituirana kao sintetička figura jednog određenog načina djelovanja, kao ljudsko iskustvo drugosti i odnosa, kao univerzalno prepoznatljiva vrijednost, kojoj biblijska objava pripisuje jedinstvenu istinu s obzirom na eshatološko konačno ispunjenje vjerničkog subjekta. Njezi-

81 Usp. M. Heidegger, Essere e tempo, Longanesi, Milano, 1976, 172 ss.

82 Usp. P. Sgroi, Ospitalità, 65-80.

83 Usp. E. Pulcini, La cura del mondo. Paura e responsabilità nell'età globale, Bollati Boringhieri, Torino, 2009.

84 Usp. C. Castiglioni, Tra estraneità e riconoscimento, Mimesis Eduzioni, MilanoUdine, 2012, 223. 
na složena artikulacija ponajprije je konfigurirana kao relacijska i stoga suštinski moralna stvarnost.

Potrebno je odrediti kako konfigurirati gostoljubivo prihvaćanje unutar teološko-moralnog diskursa kao konstitutivne stvarnosti u okviru kršćanskog moralnog djelovanja. Možemo se zapitati mogu li se moralni intersubjektivni odnosi izjednačiti s gostoljubivim prijemom kao konstitutivnim koji je po svojoj prirodi otvorenost drugosti.

Temeljne antropološke strukture gostoljubivosti nude nam premise da što potpunije razumijemo njezinu etičku konzistentnost, te nam pomažu u postavljanju temelja njezine moralne objektivnosti. Zadaća utvrđivanja njezine etičko-teološke figure potječe od pokušaja njezine prve definicije, kako u biblijskoj tako i u filozofskoj sferi, u interdisciplinarnom pristupu koji nam pruža nužno produbljivanje kategorije, kako bismo mogli shvatiti njezine naknadne implikacije u ljudskom djelovanju u etičko-teološkoj sferi ${ }^{85}$.

Biblijsko svjedočanstvo o gostoljubivom prihvaćanju, izvorno utemeljujućem i normativnom za moralni diskurs ${ }^{86}$, govori nam o gostoljubivom Bogu koji bezuvjetno prima svakoga. Taj precizan oblik, koji njegovo djelovanje poprima kroz povijest spasenja i koji se samom svojom prirodom konstituira kao autoritativna instanca na teološkom horizontu, otkriva smisao gostoljubivosti kao oblik „bezuvjetne samo-predanosti” upisane isključivo u posebnost Božjeg djelovanja. Ne postoji nikakva razlika između njegova bića i njegova djelovanja, jer se njegova gostoljubiva manifestacija podudara s njegovim gostoljubivim djelovanjem, koje nam restituira istinu o njegovu biću. Ona izražava njegovu najdublju istinu, gdje je dana ontološka i moralna koincidencija. Ta kružnost između moralne i ontološke instance dana je u njihovoj izvornoj vezi, koja nije posljedična, nego je uzajamna referenca i poistinjenje ${ }^{87}$.

Fenomenologija intersubjektivnosti daje nam osobu u relaciji kao ontološki temelj gostoljubivog prihvaćanja ${ }^{88}$ koji, u svjetlu objave, postaje hermeneutički put i sam razlog njezine vjerodostoj-

85 F. Torralba, „No olvidéis la hospitalidad” (Heb 13,2), 8.

86 Usp. D. Abignente, S. Bastianel, Le vie del bene. Oggettività, storicità, intersoggettività, Il Pozzo del Giacobbe, Trapani, 2009, 10.

87 Usp. P. Sequeri, „La nozione di persona nella sistematica trinitaria”, Teologia, 10/1(1985), 34.

88 Usp. P. Coda, „Per una ontologia trinitaria della carità. Una riflessione di carattere introduttivo", Lateranum, 51 (1985), 61-62. 
nosti ${ }^{89}$. Dinamika međuljudskih odnosa $u$ gostoljubivom odnosu podrazumijeva postojanje-s-drugim i bitak-za-drugog, u kontinuiranom pokretu otvorenosti prema drugosti u agapičnom poretku ${ }^{90}$. Ta je dinamika u potpunosti upisana u temelj registra kršćanskog moralnog djelovanja, u kojem dvostruka zapovijed ljubavi, prema Bogu i prema bližnjemu, kao jedinom činu, pronalazi potvrdu njegove realizacije u prihvaćanju drugosti ${ }^{91}$.

Polazna točka za analizu gostoljubivog iskustva, u njezinoj moralnoj dimenziji, jest savjest koja je živi, to jest sloboda kao odnos prema drugosti ${ }^{92}$. Specifičnost gostoljubivog prihvaćanja $u$ kršćanskoj tradiciji ima težnju da se konstituira kao moralno dobro. Možemo li govoriti o razlici gostoljubivog prihvaćanja kao izvorno ljudskog, u usporedbi s oblikom što ga gostoljubivost preuzima $\mathrm{u}$ kršćanskoj intenciji na razini kategorijalnog sadržaja ${ }^{93}$ ? Biblijska tradicija kaže ne, jer upravo onoj izvorno ljudskoj donosi njezinu konačnu istinu.

Kategorija gostoljubivosti kao bezuvjetno prihvaćanje baca posebno svjetlo na Kristovo otajstvo i njegovu ljubav, na dar sebstva za čovjeka ${ }^{94}$, kao i na razumijevanje smisla bezuvjetne predanosti ${ }^{95}$ gdje je „oblik Božje istine oblik same istine ljubavi: bezuvjetna predanost sebe životu drugoga" 96 .

Bezuvjetno gostoljubivo prihvaćanje konstituira se kao posredovanje upravo ove ljubavi, koja komunicira spasenje predodređeno svakom čovjeku što ga je Isus donio u povijest. Ta bezuvjetna predanost u konačnici je bit agape koji u Kristovu spasiteljskom događaju otvara mogućnost spoznaje Božje ljubavi ${ }^{97}$. Apsolutna (bezuvjetna) dostupnost Boga čovjeku dolazi na vidjelo u praksi

89 Usp. M. Cozzoli, „La testimonianza della carità”, La Rivista del Clero Italiano, 72 (1991), 830.

90 Usp. K. Rahner, „Il comandamento dell'amore fra gli altri comandamenti”, Saggi di Spiritualità, Edizioni Paoline, Roma, 1969, 399.

91 Usp. K. Rahner, Corso fondamentale sulla fede. Introduzione al concetto di Cristianesimo, Edizioni Paoline, Roma, 1984, 578.

92 G. Vendrame, „Il problema della morale oggi”, Corso di morale I, T. Goffi, G. Piana, Queriniana, Brescia, 2004, 33.

93 F.Torralba, „No olvidéis la hospitalidad” (Heb 13,2). Una exploración teológica, 5.

94 Usp. VS: $n^{\circ}: 15,17,20,21,48,85,87,89,120$.

95 Usp. G. M. Salvati, „Ubi crux, ibi amor Dei et hominis: il soffrire umano come luogo dell'amore e dell'impegno", La sapienza della croce, 6/4 (1991), 219-225.

96 P. Sequeri, „La storia di Gesù e la ragione teologica”, Aa.Vv, V. Melchiorre, Icona dell'invisibile. Studi per una interpretazione simbolica di Gesù Cristo, Vita e Pensiero, Milano, 1981, 247.

97 Usp. M. Cozzoli, Etica teologale, Edizioni Paoline, Milano, 1991, 188. 
služenja, koju Krist objavljuje u svojoj izvornoj nakani, tako da svi mogu biti spašeni i, kao takvi, konstituirani kao motivacijski izvor za gostoljubivo djelovanje ${ }^{98}$. Teološko produbljivanje teme gostoljubivosti ne može se odvojiti od antropološkog, to jest od povijesnosti ljudske slobode, jer se ne može jednostavno izvesti iz kristološkog događaja ${ }^{99}$.

Filozofski put uvijek je polazio od određenog sukoba između filoksenije i ksenofobije (ovdje u smislu zatvaranja različitosti $u$ odnosu dobro-zlo), gdje se gostoljubivo prihvaćanje, u njegovoj simboličkoj transparentnosti (kao otkrivanje smisla ljudskog), profilira kao moralno dobro, koje uključuje slobodu subjekta. Tamo gdje se ona ponižava kao moralno dobro (neposlušnost zapovijedi), tu se djelovanje profilira kao moralno zlo (ksenofobija) ${ }^{100}$. Pojašnjenje izvorne strukture iskustva gostoljubivog prihvaćanja predstavlja temeljnu pretpostavku koja otvara mogućnost promišljanja njezine teološke istine upravo polazeći od njezine materijalne određenosti.

Biblijska nam objava potvrđuje da se $u$ relaciji gostoljubivog prihvaćanja subjekt mjeri slobodom drugih, u kojoj se također otkriva smisao „dobra” koje vjera otkriva. Taj smisao se uvijek ostvaruje/ispunjava u praktičnim, a ne teoretskim dokazima ${ }^{101}$. Moralno iskustvo čovjeka, kao izvorno samoodređenje slobode dane u gostoljubivom djelovanju, aksiološki je dokaz koji se sastoji od stvarnog iskustva u kojem subjekt sam odlučuje (kao vjernik) ${ }^{102}$, tako da gostoljubivost postaje izraz praktične intencionalnosti subjekta u odnosu na drugog čovjeka. Značenje ove nakane ne može se shvatiti odvojeno od odgovarajućeg konkretnog djelovanja $^{103}$. Gostoljubivi prijem drugoga otkriva nam „konkretan oblik” slobodne dispozicije subjekta, koji je suprotan neprijateljstvu, želji da se drugoga uništi i da se njime dominira. Konverzija neprijateljstva u gostoljubivost iz teološke perspektive opisana je u Bibliji kao moralna zapovijed ${ }^{104}$.

Naposljetku, sam temelj gostoljubivosti, kao moralne vrijednosti, identificira se u ljudskoj osobi koja sama po sebi uključuje

98 Usp. T. Goffi, „La carità: un “fare per' o ‘un essere con’?”, Rivista di Teologia Morale, 89(1991), 34-35.

99 Usp. R. Maiolini, Tra fiducia esistenziale e fede in Dio. L'originaria struttura affettivo-simbolica della coscienza credente, Glossa, Milano, 2005, 424.

100 Usp. Idem, 424.

101 Usp. Idem, 430.

102 Usp. Idem, 434.

103 Usp. Idem, 436.

104 Usp. Idem, 437. 
prirodu/kulturu i milost Kristova vazmenog Duha (u prepletanju metafizičkog, ontološkog i povijesnog) ${ }^{105}$. Ovaj etičko-personalistički kriterij ostvaruje se u međuljudskim odnosima u zajednici i oblikuje se „u svjetlu evanđelja i ljudskog iskustva” ${ }^{106}$, prakticirajući nasljedovanje Krista unutar crkvenog zajedništva, tako da se i kršćanski gostoljubivi stil konfigurira kao otvaranje i dostupnost drugima (u svojoj drugosti, a ponekad i radikalnoj razlici) ${ }^{107}$, u obliku skrbi i brige za drugoga ${ }^{108}$.

\section{CHRISTIAN THEOLOGICAL-PHILOSOPHICAL EXAMINATION OF THE FOUNDATIONS OF HOSPITALITY}

\section{Summary}

The research carried out in this presentation offers us a moral perspective of hospitality in which the believing freedom is configured as an intentionality of faith. Both the research in the biblical part and in the philosophical one, have circumscribed the foundational structures of hospitality as universally anthropological in its theological connection and intrinsic human dynamic.

In this way, the premises of the overall hermeneutics of human hospitability are outlined in the light of Revelation, in which the mystery of Christ becomes the theological place of his full and definitive comprehension, and its sequela as a form of its full realization.

The phenomenology of inter-subjectivity presents the person in relationship as the ontological foundation of hospitality which, in the light of Revelation, becomes the hermeneutical path and the very reason for its credibility. The dynamics of interpersonal relationships in a hospitable relationship imply being-with-the-other and being-for-the-other, in a continuous movement of openness to otherness in the agape order. This dynamic inscribes it fully in the foundation of the register of Christian moral action. The original human, described by the biblical revelation, showed his ability to

\footnotetext{
105 Usp. GS 51.

106 GS 46.

107 Franjo, Apostolska Pobudnica Gaudete et Exultate, (19. 3. 2018.), 96. [pristup 23. 5. 2018.], http://w2.vatican.va/content/francesco/it/apost_exhortations/documents/papa francesco_esortazione-ap_20180319_gaudete-et-exsultate.html.

108 Usp. P. Sgroi, Ospitalità, 96.
} 
disclose the sense of God's original intention in welcoming hospitable, as the act of conscious and responsible freedom for the good of the other, and as a gift and care, able to overcome any strangeness/difference, even the most radical.

Key words: hospitality, care for others, self-commitment, intersubjectivity, the virtue of hospitality 